\title{
Conquests of Memory: Franciscan Chronicles of the East Asian Church in the Early Modern Period
}

\author{
Liam Matthew Brockey \\ Michigan State University, Department of History, 506 East Circle Drive, Old Horticulture, Room 256. \\ East Lansing, MI 48824, USA \\ e-mail: brockey@msu.edu \\ ORCID iD: http://orcid.org/0000-0002-5855-313X
}

Submitted: 3 November 2015. Accepted: 28 April 2016

\begin{abstract}
This essay examines the ways in which Franciscan authors recounted the history of their missions in East Asia from the sixteenth to the eighteenth century. Key differences between Franciscan authors and those of other orders are highlighted, with special emphasis placed on disputes over precedence in the Asian mission field, over privileges accorded by the papacy for missionary activity, and over the prestige secured by acts of pious heroism and appointments to high ecclesiastical offices. Chronicles served as important adjuncts to the face-toface rivalries of Catholic religious orders, with the Franciscans dueling their peers for pride of place in historical memory. The publication of Franciscan histories in Europe ensured that the conflicts between orders extended around the globe, while their original intention was to consolidate the memories of distant efforts to plant and grow the church.
\end{abstract}

KEYWORDS: Franciscan; History; History writing; Japan; China; Philippines; Southeast Asia; Missionary; Martyr; Memory.

Citation / Cómo citar este artículo: Brockey, Liam Matthew (2016) "Conquests of Memory: Franciscan Chronicles of the East Asian Church in the Early Modern Period". Culture \& History Digital Journal, 5 (2): e015. doi: http://dx.doi. org/10.3989/chdj.2016.015.

RESUMEN: Conquistas de la memoria: crónicas franciscanas en torno a la Iglesia en Extremo Oriente durante la Edad Moderna.- Este artículo examina el modo en el que los franciscanos narraron la historia de sus misiones en Asia oriental durante los siglos XVI a XVIII. Se pone de relieve algunas diferencias esenciales entre los autores franciscanos y los de otras órdenes, dando particular atención a los debates sobre precedencia en el campo misionero asiático, sobre los privilegios concedidos por el papa para la actividad misionera y sobre el prestigio que conllevaban los actos de heroísmo devoto y el nombramiento para desempeñar altas funciones eclesiásticas. Las crónicas sirvieron como importante complemento en las disputas entre las varias órdenes religiosas, donde los franciscanos se confrontaron con sus pares para ocupar un lugar de honra en la memoria histórica. La publicación de las historia franciscana en Europa permitió que los conflictos entre órdenes se extendiesen a todo el globo, aunque su intención original era la de preservar la memoria de los esfuerzos realizados para implantar y hacer crecer la Iglesia en espacios distantes.

PALABRAS CLAVE: Franciscanos; Historia; Cultura escrita; Japón; China; Filipinas; Sudeste asiático; Misioneros; Mártires; Memoria.

Copyright: $\mathbb{C} 2016$ CSIC. This is an open-access article distributed under the terms of the Creative Commons Attribution License (CC BY) Spain 3.0. 
Frei Paulo da Trindade opened his monumental history of the Franciscans in Asia with an unusually candid acknowledgment. The impetus for writing his Conquista Espiritual do Oriente, he admitted, came from a book he had chanced upon, one identified only as having been written in Italian and printed in Rome. Such was the outrage he felt on reading it that he was compelled to respond; the honor of the Franciscan order was at stake. "It is only natural for children to feel the harm done to their parents," he wrote at the start of his Reader's Prologue, "and so fitting the desire to avenge them and go forth to defend their honor that, if only the children take care not to be immoderate in their efforts, they are more worthy of praise than censure." Feeling the insult to his spiritual family as acutely as he would have felt an injury to his flesh and blood, Trindade countered with a massive outpouring of scholarship. The accusation, he argued, was one made with "no less temerity than impudence" - the Italian book alleged slanderously that "the friars of St. Francis in India did not occupy themselves with making communities of Christians, but only with burying the dead and singing Requiem masses" (Trindade, 19621967, I: 5).

A distinguished theologian, born in Macau but who had lived most of his life in Portuguese India, Frei Paulo da Trindade (1570-1651) refused to let such insults alone. He spent six years examining Franciscan archives in Goa and corresponding with informants elsewhere in the Estado da Índia in order to write a chronicle of the Friars Minor in Asia that would silence all critics. Part rebuttal, part paean to Franciscan missionary heroism, Trindade's account did not mention other histories of missionary gains in Asia, such as the widely-circulated and oft-reprinted histories of the Jesuits in Japan, China, and India. Each order that participated in the advance of the church was well within its rights to trumpet the worthy deeds of its members. To cast aspersions on the efforts of others, however, was excessive. So Trindade might have approached his task with greater humility vis-à-vis his fellow authors, but sharp words were necessary. Speaking of his history of the Observant Franciscan Província de São Tomé, he wrote, its intention was "to show to the world the falsity of the abovementioned author who, with so little reason, sought to inveigh against this Holy Province on matters for which it deserves great praise." To be sure, Trindade retreated from invective as he concluded his preface, hoping that "divine goodness would favor our intentions, which are none other than the glory of His Holy Name, honor for our sacred Franciscan order, and credit and reputation for this Holy Province of São Tomé" (Trindade, 1962-1967, I: 6).

This formulation gets to the heart of the historical enterprise as it was conceived by early modern chroniclers from religious orders. Their goal was to celebrate the memory of missionary endeavors and pious works, acts that increased the honor of their communities and the glory of God. That such historical writings are filled with devotional sentiment and prayers is not remarkable; that they spent so much energy on the defense of honor is.
After all, is it not a commonplace to assert that members of religious orders had "fled the world" and its cares, especially the concern for worldly honors and riches? Indeed, as individuals they did; individual priests, monks, and friars adhered to their personal vows of poverty and often refused offers of academic degrees and prelacies. But as corporations, that is, as groups with specific group identities expressed in written rules or "ways of proceeding" (to use the Jesuits' oft-repeated formulation), they were acutely aware of their social prestige. In the secular realm, honor was the gentleman's garb; among religious, it was the order's habit.

This article seeks to understand how early modern Franciscan authors understood the history of their activities in East Asia. The best way to comprehend how they framed their historical writings is through the prism of honor, that is, the corporate honor of the Order of Friars Minor. In this regard, the chroniclers to be discussed here resemble contemporary secular authors, men who often placed issues of honor at the top of their list of concerns. To be sure, among religious writers it was by no means only the Friars Minor who were concerned for honor: They were no different than their peers among the Jesuits, Dominicans, or Augustinians, to name orders whose members also produced chronicles of Asian endeavors. Each congregation sought to defend its corporate honor by shaping memory through history writing, arguing for precedence in a field crowded with competitors.

Memory is admittedly a slippery term. The question immediately arises: Whose memory? Those Franciscans who read the chronicles in manuscript as internal histories of their order? Laymen and women, as well as other Franciscans and members of other orders, who read the chronicles in print? This is a difficult question to answer. But as we will see, the preservation of internal memory and the publication of heroic histories addressed both internal and external audiences. The potential benefits of such attempts to conquer memory were considerable: Increased public recognition of an order's piety and its saints' intercessory powers in heaven; augmented endowments for missions or communities; greater numbers of recruits; a larger hold on the imagination with regard to overseas missions. Such were the rewards reaped, for example, by the Society of Jesus, whose members were comparative latecomers to the Asian missions (except for Japan). Not only did Jesuit reports and histories impel generation after generation of men to pursue missionary glory in the East, their publications in Europe undeniably helped shape the modern Western imagination with regard to overseas enterprises.

What, then, is distinct about Franciscan historical writing regarding the early modern Asian missions? As Trindade's comments indicate, there was a strong desire to set the record straight about perceived errors circulating in print. This desire to correct suggests that the Franciscans did not pursue history writing with the same vigor as their counterparts among the Jesuits, for example. Trindade stated as much, remarking that his predecessors took more care to "occupy themselves with doing works 
worthy of memory than with publishing their praises and eternalizing their names, leaving many buried in oblivion" (Trindade, 1962-1967, I: 6). So the task that he undertook was marked by the desire to restore the Franciscans to their proper place within the history of the Asian church. Like other chroniclers from his order, he insisted on the primacy of the Franciscans within the missions: They had been the first to reach Asia, and their pedigree in those lands stretched back to the Middle Ages. Trindade also insisted on the specific privileges enjoyed by the Franciscans and their close links to the church hierarchy (notably, the numerous prelacies that friars had held over time). And, finally, he and his fellow Franciscan historians underscored the pious heroism of their confreres: Wherever the friars went, they preached more vigorously than other missionaries; they suffered more heroically; and their martyrdoms occasioned more miracles. ${ }^{1}$

These aspects of Franciscan historical writing about Asia will be examined in the discussion that follows, revealing the defining characteristics of the friars' approach to the past during the early modern period. Important chronicles, whether printed or manuscript, will be identified, as well as other publications, from within or without the Franciscan family, which influenced Franciscan writing. This analysis is not, however, an exercise in the "history of the book", nor an attempt to gauge Franciscan writing about Asia. As such, Franciscan descriptions of East Asian polities and cultures will not be a focus here, regardless of their importance for early modern European understanding of Asia. Rather, this discussion will examine Franciscan writing about Franciscan history in Asia, an activity which sought to claim and preserve the memory of their deeds in a region to which other orders also worked.

\section{MATTERS OF PRECEDENT}

An overview of the recent historiography of pre-modern Europeans in Asia reveals a dominance of Jesuit narratives. Indeed, given the ubiquity of the figure of Matteo Ricci (1552-1610), it is forgivable to assume that the Jesuits were pioneers in that region. This dominant position was a long time in the making; it began in the early modern period. In the Jesuits' chronicles of their missions, one notices a matter-of-fact quality. Readers of Matteo Ricci's diaries, edited, augmented, and published by Nicolas Trigault as De Christiana Expeditione apud Sinas (first ed. 1615), or Danielo Bartoli's Dell'Asia (3 vols., 1653-1663) learned first that Asia existed, then that the Portuguese navigators crossed the seas to reach its shores, and finally that Francis Xavier (1506-1552) began to spread the faith among the peoples of the East. The repetition of stories about the Apostle of the Orient after his beatification in 1619 and canonization in 1622 solidified the claims about his primacy in the minds of European readers - and later scholars. ${ }^{2}$ Tales found in these same books about such figures as Ricci in China and Francesco Buzomi (1575-1639) or Alexandre de Rhodes (1591-1660) in Vietnam led many to conclude that the Jesuits were indeed the missionary pioneers of East Asia. Expansively named book titles thus did the work of conquistadores. Trigault's many editions and translations overwhelmed by their display of how the "Christian Expedition to China" was a Jesuit affair, as Bartoli's voluminous tomes argued that the Society of Jesus also dominated efforts in India and Japan. But the Jesuits had not been the first missionaries to arrive in East Asia. The Friars Minor had worked in the region since the time of the Mongols. Moreover, the friars had accompanied the first Portuguese voyages along the sea route to India. Erasing them from their rightful place in the first chapters of the story of the spread of Christianity in Asia was justly felt as an affront to Franciscan honor.

It is therefore no surprise that early modern Franciscan chroniclers sought to reclaim the memory of their pioneering efforts. After all, it was well known in sixteenthcentury Europe that the Franciscans had made their way East in the medieval period. Those adventures were considered among the many accomplishments of the early friars and thus repeated in institutional histories that circulated among Franciscans. Perhaps the most influential of the chronicles where the story of the early friars in Asia was recounted is the Crónica da Ordem dos Frades Menores (3 vols., 1557-1570), written by Frei Marcos de Lisboa (1511-1591) in Portuguese and widely translated. This massive book included several chapters on the story of the Franciscans who followed the Silk Road to the lands of the Great Khan - understood to be Central Asian territories ruled over by descendants of Genghis Khan (1206-1227), although these places were not precisely situated in medieval or early modern texts. Frei Marcos recounted how Pope Innocent IV (r.1243-1254) sent priests to the "most ferocious and cruel Tartar people, who seemed intent on destroying the whole world." Summoning friars to act as ambassadors, Innocent sent them on two routes into Asia with news of the gospel, "so that at least the fear of God might curb their many cruelties." The southern route took one Dominican-led expedition to Persia. The northern expedition, a Franciscan group led by Giovanni da Pian del Carpine (1180-1252), made it to Tartaria in 1245 after suffering great hardships along their route. ${ }^{3}$ Having passed through "many labors, dangers, and weakness from hunger, since they ate nothing but wheat boiled in water, and to drink they had to melt water that was frozen over a fire," they were rewarded with dramatic results. In the succinct résumé of Frei Marcos: "They made great conversions to the faith among the Tartars, and had a custody or vicariate of many convents among the Tartars"4 (Lisboa, 1615: 17v).

The progress of these churches is not mentioned, but Frei Marcos's later chapters mention another set of Franciscan emissaries, one sent by Benedict XII (r.1334-1342) into Tartaria nearly a century later, in $1341 . .^{5}$ Soon after they arrived at their destination, this group led by Giovanni de' Marignolli (called João de Florença here) was expelled to lands further east by a Muslim usurper of the Tartar throne - who had, however, first delivered some of the friars to a Muslim crowd that "very cruelly cut them to pieces with swords". In those more distant Eastern lands, 
referred to as the "most vast empire of the Great Khan", Marignolli was received cordially and given a "general license to preach throughout his empire". Carrying a great cross in his hand, Lisboa reported, "preaching with his friars in all places, he converted many pagans to the faith of Christ, and built many churches, always preaching the name of Christ, without fear" (Lisboa, 1615: 220r/v).

Frei Marcos's chronicle only extends to the papacy of Urban VI (r.1378-1389), thereby leaving accounts of later Franciscan progress in Eastern lands to other hands. The story of these medieval friars and their successes would, however, be replicated in other early modern histories, texts which were dedicated to recounting triumphs in the newly-discovered parts of East Asia. Linking the medieval missions to the early modern ones - in light of the gap of two centuries - proved difficult. The astute reader asked: Was the Tartaria of these medieval expeditions actually in East Asia? Or was it situated on the vast steppes of Central Asia? Medieval geography had no firm answers to these questions, and early modern travelers did not visit the area until the seventeenth century. The association of Tartary with Yuan dynasty China was nevertheless a convenient one for Franciscan chroniclers. By claiming that their men had gone to the territories ruled over by the descendants of Kublai Khan (r.1260-1294), they could justify their presence in the same regions later on. To be sure, at least one of the early Franciscans, Giovanni da Montecorvino (1247-1328), served as Bishop of Cambaluc in the city that would later be known as Beijing. But the clear linkage between the Tartar city and the Ming dynasty imperial capital would only be established for European readers in the seventeenth century and would be a matter of dispute in Europe for many decades.

The goad for the Franciscan historians was likely the Jesuit Nicolas Trigault's claim that Francis Xavier was the founder of the China mission (Trigault, 1615: 127). Frei Paulo de Trindade and Frei Jacinto de Deus (1612-1681) responded to this assertion by claiming the precedent of their brethren's efforts in that very region. Trindade's second chapter, following one dedicated to St. Francis of Assisi's commitment to "preaching the faith and converting the infidels", asserts that later friars acted on this same impulse, and that there was "no corner of the world to which they did not take the light of the Holy Gospel", including Russia, Bosnia, Bulgaria, Egypt, and Grã Tartaria. Here Trindade repeats (and at times embellishes) assertions made by Frei Marcos de Lisboa, insisting that the expeditions to Tartaria resulted in the conversions of "infinite numbers of those barbarous infidels". Moreover, the friars even baptized a "brother of the emperor named Octogense," a convert whose evident sanctity occasioned many miracles (Trindade, 1962-1967, I: 9, 13, 16).

Frei José de Jesus Maria, who produced a history of the Asian missions in the middle of the eighteenth century, also made sure to underscore the primacy of the friars in the Eastern missions. The manuscript history Azia Sinica e Japonica focuses on East Asia, and especially on the Portuguese colony of Macau. A Portuguese friar about whom little is known beyond the fact that he lived in Macau circa
1745, Jesus Maria insists, using the Jesuits as his foil, that Franciscans wrote a large part of the preface to the early modern missions. His synopsis of the history of the church in Azia Maior from the time of St. Thomas the Apostle until the arrival of the Portuguese remarks upon the presence of Syrian Christians, including Arians and Nestorians, in China. Jesus Maria cites the finding of the Nestorian stele in Xi'an, reported by Jesuit missionaries in 1625 , that was inscribed with a text reproduced and translated in the Jesuit Athanasius Kircher's China Illustrata (first ed., Amsterdam, 1667). Until the thirteenth century, however, "the Faith of Christ in this Azia Mayor was alternately received and repudiated", until the moment when the Great Khan conquered his vast domains. Hearing this news, Frei José recorded, Pope Nicholas IV (r.1288-1292) — the first Franciscan to wear the papal tiara- decided that the "sons of St. Francis would have the glory to be the first missionaries and the first prelates of the churches of those dilated empires." After recording the names of the early Franciscan travelers to Tartaria, this chronicler passes quickly over their heroic acts — "raising oratories, founding churches, making hospitals, baptizing princes and innumerable people, torching idols, destroying pagodes, uprooting superstitions, and undoing sects"- before lamenting the destruction of these works in the midst of the wars between Chinese and Tartars after the year 1400 (Jesus Maria, 1941-1950, I: 41-48).

By pointing to remote precedents in East Asia - even if there remained ambiguity about the distinction between China and Tartaria - Franciscan authors established their positions within a long line of succession. Filling in the gaps between the Tartary enterprises and the missions of their own time (here, mostly the seventeenth century) was a much greater challenge. Frei Marcos de Lisboa was able to examine archives of various Franciscan houses in Spain and Portugal, sifting through medieval documents in order to craft his narrative. He learned of the thirteenth and fourteenth century missions out along the Silk Road since reports about them circulated as far as Iberia. Records of the papal pronouncements that spurred these voyages and conceded Franciscans privileges to organize and administer new churches in distant lands were also mentioned in Lisboa's chronicle.

Frei Marcos de Lisboa also benefitted from the fact that the Order of Friars Minor had only one branch during the period chronicled by him. The division of the Franciscan family in the fifteenth century, when it separated into Observant and Conventual wings, and the subsequent emergence from the Observants of Discalced, Capuchin, Recollect branches, as well as their female correspondents, significantly impeded the writing of the order's history. Within Portugal and its overseas empire, there were two main branches after the beginning of the sixteenth century, the Observants and the Reformed Observants. This second group, also known as Discalced Franciscans (in Portugal, called Capuchos $^{6}$ ), had enough similarities with the Observants to generate jurisdictional confusion. Moreover, the fact that Franciscan communities across Maritime Asia were only gradually grouped into provinc- 
es (with borders disputed between Portuguese and Spanish Franciscans) meant that there was no single repository for documents. ${ }^{7}$ Unlike the Jesuits, who had a centralized structure and obliged province-level narratives to be sent yearly to Rome, the Franciscans could not count on a ready reserve of materials for their histories. To put order in the chaos of Franciscan sources was thus their first priority as chroniclers when they set to their task in the late sixteenth and seventeenth centuries.

Both Frei Paulo da Trindade and Frei José de Jesus Maria were aware of the challenges they faced in seeking to produce general histories. Other Franciscan authors limited themselves to treating specific events or particular missionaries, tasks that did not depend on rich archiveswhere an accumulation of sources about the martyrdom of a set of friars, for example, would suffice. By contrast, Trindade's Spiritual Conquest of the Orient was intended as a sweeping history of the Observant Province of São Tomé, which had boundaries stretching from the Cape of Good Hope to Japan. But even from the capital of the Estado da India, Trindade had difficulty surveying the historical terrain of Franciscan Asia. He mentions the laborious task of collecting information, "especially about older things, because of the great carelessness on the part both of authors who wrote about Indian matters and of our own men of those times" (Trindade, 1962-1967, I: 6).

Straightening the twisted writings of others compounded the historian's difficulties, a later Franciscan chronicler affirmed. In his Vergel das Plantas, e Flores da Provincia da Madre de Deos dos Capuchos Reformados (Lisbon, 1690), Frei Jacinto de Deus, a Macau-born Discalced friar who spent most of his life in Goa, adopted a biblical metaphor for his effort to make sense of the friars' past by rummaging in scattered and unreliable sources. The story he chose was that of the priest Nehemias, who had to seek the sacred ancestral fire of the Jews in Persia [II Macc. 1: 19-22]:

\begin{abstract}
It is manifest how difficult, \& almost impossible it is to penetrate the obscure caverns of antiquity; time changes everything, consuming all. We seek the remains, \& we infer the effects. Well known is that miraculous event recounted in the first chapter of the second book of Maccabees. The sons of Israel hid the holy fire in a deep cave. Nehemias discovered the place but did not find the fire, because it had turned into water over time. We seek to discover past events, \& either we do not find them, or we find them different from what they were: Tradition affirms and texts relate, nevertheless, that it was thus, and we should believe them unless we wish to dismiss everything. Imitating Nehemias, I travelled to various places, digging through much earth, to uncover the lives and heroic deeds of our predecessors. In very ancient fragments, \& in almost indecipherable writings, I found the memory of some; about others, in the memory of the elderly who either spoke of them or heard from others who knew and communicated with them.
\end{abstract}

The memory of one's elders, Frei Jacinto admitted, was not the most reliable source; the written work of his predecessors was more solid. He mentions a text by Frei
Francisco Negrão, the author of a chronicle that has since been lost, and Trindade's history, lamenting that neither work was published by the time he wrote and that neither was available to him in Goa in the 1670s. "With this lack, and the dearth of reports," Frei Jacinto claimed, "it required great labors before I could discover the fire hidden in the well of antiquity and in the dark cavern of oblivion, using files and archives, relations and papers that some curious individuals preserved" (Deus, 1690: Reader's Preface).

The end result of these investigations into the obscure corners of memory was, needless to say, that the brilliant pedigree of Franciscan efforts was made to shine more brightly. Echoing the assertions made by Trindade, a generation previously, Frei Jacinto de Deus insisted that his brethren could claim precedence in Asia and elsewhere. He proclaimed his intention clearly in the title of his very first article: "The Priority of the Friars Minor in All of the Service to God will be Demonstrated". Here, the distinctions between Capuchos and the other Franciscan families were conveniently collapsed into one in order to serve the author's purpose. The Franciscans "were the first ones to plant the tree of the Cross in the West Indies, \& to shine the light of the Gospel into the darkness of Idolatry: Frei João Peres de Marchena, of the Portuguese nation, son of the Holy Province of Arrábida, in the company of the same Christopher Columbus, the first discoverer of that New World ${ }^{9}$; they were the first to light the torch of faith in the dark lands of Brazil: Frey Henrique of Coimbra and his companions; these same men were the first who sowed the seeds of the Gospel in the Orient, \& the first who traversed all of this vast \& spacious Indian Empire" (Deus, 1690: 117). ${ }^{10}$

When he reached the lands at the farthest corner of Asia, however, Frei Jacinto de Deus had to concede that the Franciscans had not been the first emissaries of the Church. He admitted grudgingly that "if in any place, such as Japan, they came to cultivate second," the friars' zeal nevertheless surpassed that of the (Jesuit) pioneers - a theme which will be discussed in greater detail below. Frei Jacinto continued to place asterisks next to all of the widely-touted Jesuit inaugural victories in the East, especially in China: "Although that great light of the Orient, St. Francis Xavier, undeniably made the first proclamation of Faith [on its shores], yet he could not enter into the interior of the Empire" (Deus, 1690: 119). The true pioneer in the sertão do vasto Imperio da China, he claimed, was actually a Dominican, Frei Gaspar da Cruz (c.1520-1570), who had a brief stay at Canton in 1556. But this triumph was also a Franciscan victory, Frei Jacinto reasoned, "because the sons of our padre St. Dominic, and those of our holy religion are through mutual love one in the same, and our Holy Patriarchs wanted a union that would be identical, so if they were the first, we would not remain second." Just in case this rationale did not prove compelling to his readers, Frei Jacinto de Deus had other grounds for his broader point. He asserted to his readers that the first apostles to enter the Ming Empire were Franciscans, not Jesuits: Fray Pedro de Alfaro 
(d.1580), custodian of the Philippine Discalced friars, had attempted unsuccessfully to penetrate China in 1579 , before Michele Ruggieri and Matteo Ricci tried the same (Deus, 1690: 119). Regardless of the long-term outcome of Alfaro's mission, it did occur a few short months before the Jesuit pair secured permission to remain after the end of the Canton fairs. Of course, other Jesuits had preceded the two Italians, but the Franciscan chronicler was most likely unaware of those earlier missions. ${ }^{11}$ Knowledge, for that matter, would not have served his polemical intent.

\section{FRANCISCANS AT THE FOREFRONT}

More than just the question of precedence in the mission fields of East Asia, the perception of Franciscan primacy in the early modern Asian church was of great concern to its chroniclers. Here was the trump card that the friars could hold against the Jesuits and their seemingly invincible élan. The Society of Jesus, approved by Pope Paul III (r.1534-1549) as recently as 1540, was a relatively new organization. That novelty was a significant weakness; it meant that the Jesuits did not enjoy the longstanding relations with princes and prelates that the Franciscans did. By the time it occurred to the papacy that the new overseas territories needed missionaries and bishops, the first group to come to mind was not the secular clergy but the regular clergy - and not upstarts like the Jesuits, except occasionally. To the friars therefore fell many of the first episcopal appointments of the expanding church hierarchy. And to the friars accrued the first new privileges for missionary pastoral work, concessions that enhanced the already numerous formal capacities, exceptions, and unique powers that medieval popes had conceded to the Order of Friars Minor.

Keeping track of manifestations of papal favor was a particular pleasure for Franciscan chroniclers of the Asian missions. A common feature of their histories is the listing of archbishops and bishops drawn from the ranks of the friars, especially for territories with vast jurisdictions. Of these, the most expansive was the Archbishopric of Goa, a see with boundaries that largely matched those of the Portuguese Estado da Índia. Early on in Frei Paulo da Trindade's history, one finds a discussion of how King João III (r.1521-1557) exercised his patronage rights to secure the installation of Frei Fernando Vaqueiro (d.1535) as a suffragan bishop over the eastern territories encompassed by the vast Diocese of Funchal. ${ }^{12}$ When the new diocese of Goa was erected in 1533, Trindade reports, the king's candidate to hold the office was also a Franciscan, Juan de Albuquerque (d.1553). Although this nominee, unlike the Observant author Trindade, was a member of the Reformed Observants, his status as the Franciscan who first organized the cathedral, its chapter, and the city's parishes merited Albuquerque a prime spot in the chronicle. Trindade's list of archbishops of Goa continues with references to several Dominicans, Augustinians, and Hieronymites, conveniently ending with the mention of yet another Franciscan, Frei Bernardino de Sena (1571-
1632), who only declined to take up the archbishop's miter because he also won election as the superior general of his $\operatorname{order}^{13}$ (Trindade, 1962-1967, I: 92-100).

Later Franciscan chroniclers, such as Frei José de Jesus Maria in the eighteenth century, felt obliged to devote more pages in their histories to the role that friars played in church administration. To be sure, the Archbishops of Goa occupied the top spot, enjoying the title Primate of the Orient and close relationships with the viceroys of the Estado da Índia. Further afield in East Asia, however, things were more confused. The vagaries of communication between Goa and Macau, as well as the irruption of Dutch power onto Southeast Asian seas, the Portuguese restoration in 1640, and various other political swings in East Asia meant that the episcopal lines of succession in that region were not always clear. While other religious orders, especially the Jesuits, maintained reserves of senior priests in Macau, these individuals were not always elevated to the bishoprics that the papacy had created to administer the region's growing churches. As a result, the dioceses of China and of Japan were often left vacant, whether because candidates selected by king and pope did not reach East Asia or because incumbents left their sees. Whereas the Bishops of Japan were chosen from among the Jesuits during the period from 1588 until the effective end of the early modern mission church in 1639 (with the final cessation of Portuguese commerce with Japan), the Bishops of China came from other orders. It is worth noting, however, that the boundaries of this "Bishopric of China" were ill-defined and extended no farther than over the city of Macau for most of the time examined here. Moreover, there were significant periods, especially from 1613 until 1692, when administration of the see was entrusted to ecclesiastical governors - individuals whose privileges were often contested by other churchmen in Macau. These were the periods that the Franciscan chroniclers sought to illuminate, in the hopes of removing the shadow of usurpation that hung over their brethren who exercised such functions.

Frei José de Jesus Maria dedicates several chapters of his Azia Sinica e Japonica to discussing how Macau got its bishopric and who exercised jurisdiction over it. He cites in extenso the apostolic brief that Gregory XIII (r.1572-1585) issued on the subject in 1575, insisting that the erection of the bishopric was postponed because of the Jornada de África, King Sebastião I's ill-starred expedition to Morocco in 1578. Jesus Maria also includes a discussion about who was the first prelate to receive the title of Bishop of China - curiously, a discourse that distinguishes between two Jesuits, Andrés de Oviedo (15171577) and Melchior Carneiro (1516-1583). But Jesus Maria continues in his presentation of the matter to offer a list of all the prelates who have held jurisdiction in East Asia, even those who served as ecclesiastical governors of the bishopric in Macau for the middle decades of the seventeenth century. Unsurprisingly, the first eight names on his list of forty-eight are the Franciscans of the Mission to Tartaria, starting with "Illustrissimo Dom Frei João de Monte Corvino Franciscan, Archbishop of Cam- 
baluc or Peking, with title and exercise, ambassador and apostolic legate of Pope Nicholas V." He completes his list of bishops with a chapter dedicated to biographic sketches of those who exercised jurisdiction over Macau (in distinction to bishops with greater pretensions to jurisdiction over China), devoting its longest discussion to the arrival of Frei Hilário de Santa Rosa, who reached the city in 1742 . Then he launches into a "problematical dissertation", with the purpose of demonstrating that "Franciscan religious were the first ones responsible for all of this Christian community" (Jesus Maria, 1941-1950, I: 128-152).

So a question of honor motivated Frei José de Jesus Maria. His main point is that the medieval bishops of Cathay, that is, the Franciscan friars who traveled to Grã Tartaria, indeed exercised episcopal jurisdiction over China. Consequently, Franciscans had the right to continue to work there, even if that right was called into question by the disputes over the Chinese Rites in the seventeenth and eighteenth centuries. After all, the region was part of their order's spiritual patrimony (Jesus Maria, 1941-1950, I: 152-153). That Marco Polo's Cathay was the same as China was a point addressed by Jesuit authors over a century previously in De Christiana Expeditione, so it may seem curious that Jesus Maria felt compelled to reassert the identity of the two places (Trigault, 1615: 3). But the need for his argument was patent, because Cataio continued to be present in contemporary European cartography. Indeed, this fabled land migrated on maps over the course of the seventeenth century to beyond the Great Wall and ever towards the northeast corner of Asia before disappearing entirely in the eighteenth century. ${ }^{14}$

While it may seem that Frei José de Jesus Maria's argument properly pertains to the general consideration of precedence considered above, there were other matters at stake. The most important of these was whether the Franciscans had the right to work as missionaries in the region, something that an episcopal pedigree would ensure. Proof could be found in the specific privileges that had been conceded by popes to the Franciscans for carrying out missions and administering other church institutions in the region. Papal briefs permitting the creation of Franciscan provinces were of particular importance, and were cited oftentimes verbatim. Perhaps the most striking examples of this practice relate to the Japanese mission, although the fault line between the Spanish and Portuguese empires in Southeast Asia also occasioned disputes.

Seizing the initiative provided by a surging wave of conversions in the late 1570 s and early 1580 s, the Jesuits sought to have Japan designated as their exclusive mission territory. There is nothing surprising about this desire within the context of early modern missionization: Conquered territories in the Americas and Asia were often divided among different orders as a way of limiting conflicts. The Jesuits had been the first to arrive in Japan and had been the first to set to work cultivating the church in that remote island nation. The concession of exclusive rights to proselytize there came in a papal brief issued by Pope Gregory XIII in January 1585, within a year of the arrival of the first Franciscan friars in Japan. The two events were unrelated, however, since the Jesuits had lobbied for several years for this regime of exclusivity. ${ }^{15}$ The news, however, was not well received among the Franciscans in Europe, and their brethren in Manila, who were intent on establishing new mission territories from their base in the Philippines, responded aggressively.

The story of how the several orders pleaded with the papacy for the right to send missionaries to Japan is a complex one, and falls beyond the scope of this analysis. It is sufficient to remark that several groups of friars made their way to Kyushu and Honshu in the decade after 1585, and a few of these ended their days as martyrs. ${ }^{16}$ The tragic drama of 1597 that inaugurated half a century of bloody persecutions in Japan involved friars in the starring roles: Of the twenty-six martyrs of Nagasaki, six were Franciscans (whereas three were Japanese members of the Society of Jesus). That the friars were interlopers in Jesuit territory was a key point in the Jesuit understanding of the affair, something that would influence the memories of Japan produced by contemporary chroniclers. Within three years, however, the papacy - despite Clement VIII's reaffirmation of the Jesuits' exclusive rights to Japan in 1597- decided to permit all missionary orders to seek souls in Japan and China, so long as they arrived in the mission field through the Portuguese Estado da Índia (and not from Mexico via Manila). Rather than being the seed of the church, the blood of martyrs turned into rivers of ink to be exhausted in polemics on the history of the fledgling East Asian church.

Contradictory pronouncements from Rome, evidently influenced by curial politics, spurred more than a few battles between religious orders. The papal briefs that accorded exclusions or inclusions of missionaries in Japan were the prelude to more intense wrangling decades later over the permissions and prohibitions of the Chinese Rites. No sooner had Clement VIII's general permission for friars to work in Japan been issued than Jesuit and Franciscan chronicles of East Asia appeared in Europe. On the Jesuit side, Luis de Guzmán published his twovolume Historia de las Missiones que han hecho los Religiosos de la Compañia de Iesvs, para Predicar el Sancto Evangelio en los Reynos de Iapon (Alcalá, 1601), duly reproducing the original 1585 brief, translated for his readers into Castilian (Guzmán, 1601: 2: 649-651). This Jesuit chronicler could not do without a long disquisition denouncing his order's critics, including those friars who impugned the motives of the Society of Jesus for seeking the original order of exclusion (Ibid., 2: 645-712).

Chief among those who denounced the Jesuits was Fray Marcelo de Ribadeneira, a Philippine Discalced friar who produced a history of the Province of San Gregorio printed at Barcelona, also in 1601. In this work, entitled Historia de las Islas del Archipielago, y Reynos de la Gran China, Tartaria, Cuchinchina, Malaca, Sian, Camboxa y Iappon, y de lo sucedido en ellos a los Religiosos Descalços, de la Orden del Seraphico Padre San Francisco, de la Provincia de San Gregorio de las Philippinas, Ribadeneira cast his net widely over East Asia. For 
him, the Jesuits had no right to exclusivity — in Japan or elsewhere- since the friars had their own capacious permission from the papacy. He thus includes a Castilian translation of the brief that Sixtus V (r.1585-1590; a former Franciscan) issued in 1586, which transformed the Discalced Franciscan's custody in the Philippines into a full-fledged province. The papal decree gave the friars explicit license to create new convents "in the same Philippine Islands, as well as in whichever other lands and places in those Indies, as well as in those called the Kingdoms of China." No specific permissions from the Holy See would therefore be necessary for sending friars to any of the adjacent lands "where the conversion of the heathens to the Catholic faith can be conveniently sought" (Ribadeneira, 1601: 87). That Ribadeneira should have dedicated nearly half of his book to recounting the 1597 martyrdom of the six friars at Nagasaki is a clear indication of how literally the Philippine Franciscans intended to take Sixtus V's words - regardless of Clement VIII's earlier pronouncements (Ibid., 349-711).

One should not suppose that Ribadeneira only targeted the Jesuits in his writings. He also intended to redraw the Franciscan map of Asia, positing clearer divisions between the Portuguese Observants of the Province of São Tomé and the Portuguese Discalced friars of the Province of Madre de Deus. The latter province, created in 1593, separated the Asian custodies from the Province of Arrábida, a jurisdiction primarily situated in continental Portugal (Deus, 1690: 58). Ribadeneira was particularly interested in establishing precedents for where Castilian Discalced Friars might legitimately work both inside and outside the Philippines. From the perspective of the Discalced Friars at Manila, they possessed the right to create houses in places that lay beyond the heart of the Portuguese Estado da Índia: Southeast and East Asia, from Malacca all the way to Japan, by way of Gran China and Tartaria. A principal reason for staking this claim to such a vast spread of territories was the ill-defined nature of ecclesiastical jurisdictions in East Asia — an ambiguity rooted in the disputes between the Spanish and the Portuguese empires and in an inadequate knowledge of the region's geography in Rome.

In light of the Jesuit precedent with regard to Japan, exclusive rights to one region or another might be obtained if it could be convincingly argued that a particular group had claimed them early on. Here is where chroniclers played an important role: They published works destined for large European audiences (Castilian and Italian readership, especially) that could help associate the Franciscan name with particular territories. The 1601 date of his chronicle is therefore significant. By that date, the only significant missionary advances in East and Southeast Asia had been made in Japan. Everywhere else, from the colonial cities of Malacca, Manila, and Macau to the kingdoms of Cambodia and Siam, and even the Ming Empire, missionary efforts were still incipient and communities of resident friars remained small. By 1601, Matteo Ricci had only just reached Beijing; a mere handful of Jesuits tended to miniscule flocks within China; the sto- ried waves of conversions that would come from Jesuit efforts there, as well as in Vietnam, were still decades in the future. Ribadeneira's 700-page history of the Provincia de San Gregorio therefore laid claim to areas which had yet to be firmly associated with any other order - regardless of how tenuous the Castilian Discalced friars' presence in them was.

Fray Marcelo de Ribadeneira also took aim at Portuguese Franciscan pretensions. The Philippine friars sought to establish themselves in areas that, according to the imperial logic that guided missionary expansion, belonged to their Portuguese confreres. For example, the Discalced convents in Malacca and Macau were founded by friars from Manila. According to Ribadeneira's account of the creation of the first Franciscan house in Macau in 1579, that city's Portuguese inhabitants "were not only pleased that they built a church and a house, remaining there to stay, but also helped them with alms." In his telling, far from being viewed as interlopers, the friars were lauded for the "holy poverty that they demonstrated with their exemplary lives, always dealing with the poor of the hospital, curing and comforting them" (Ribadeneira, 1601: 96-97). A similar reception was accorded the friars from Manila in Malacca, where the leader of the same group that had been in Macau created a new convent in 1580 . A hermitage outside the city walls, conceded to them by the Portuguese authorities, continued to function as a spiritual pole "because the people are greatly devoted both to the church and to the friars" (Ibid., 162). The message sent with these passages seems clear: The Castilian Discalced friars were appreciated by the Portuguese. They should not be barred from establishing communities in Portuguese colonial cities, or in areas beyond those colonies further to the West, such as Cochinchina or Siam.

From a different perspective, the gestures recorded by Ribadeneira were examples of Castilian overreach into Portuguese territory. His chronicle downplays the problems caused by such moves. He describes the time spent by the friars in Macau in 1579 as a spiritual idyll, with the local clergy and Portuguese inhabitants responding to the pious example of the Franciscans' lives (Ribadeneira, 1601: 96-99). Despite this hospitable welcome, the Portuguese still preferred that the friars "would go to build a convent in Malacca, where the ships heading from Macau to India take on supplies, and where there is much dealing with heathens from various rich and populous kingdoms" (Ibid., 161). The same event was not recorded in quite the same way by Frei Paulo da Trindade, who wrote his Conquista Espiritual three decades later. Unlike his Castilian fellow chronicler, this Portuguese historian recorded that the presence of friars from Manila caused an uproar: "After they had founded the convent of Our Lady of Porziuncola in Macau, some residents of that city raised a great persecution against them, taking it poorly that Castilians came to Macau because of the great losses that they suffered from them in their trading." The reason for the hasty departure for Goa - and the fatal shipwreck - of their leader, Pedro de Alfaro, was the summons he had re- 
ceived to account for the friars' actions before the viceroy of the Estado da Índia. The Italian friar who was left behind at the new convent, Giovanni Battista Lucarelli (d.1604), found it difficult to calm the tormenta that arose against the Franciscans at Macau. Within a few months, he embarked himself for India himself (Trindade, 19621967, III: 378-380).

According to Ribadeneira, things went much more smoothly for the friars after their departure from Macau. Some of them regrouped in Cochinchina, where they set to work spreading the gospel and were even able to present the Christian message at court. Others found their way to Siam. ${ }^{17}$ Lucarelli, simply called Juan Baptista (or João Baptista) in the chronicles, continued towards India but made a stop in Malacca, where the city's bishop and captain received him well. But this welcome did not win the friars from Manila a longer stay than they had enjoyed in Macau - Malacca was indisputably Portuguese territory, and the friars were soon obliged to turn over the new convent to their Reformed Observant brethren. Here is the scene as presented in Ribadeneira's account:

Being asked to do so by the Portuguese, the Castilian padres left. Immediately, there arrived Portuguese religious who were also Discalced friars from the very reformed Province of Arrábida of Portugal, who live with great sanctity, edifying the people with their good example, and converting many infidels to our holy faith (Ribadeneira, 1601: 163).

Frei Paulo da Trindade gave a longer description of these events, relating how Lucarelli made his way to Rome in the mid-1580s in order to discuss the work of his confreres in Asia with Sixtus V. Both pope and minister general were thus prompted to reorganize the Reformed Franciscans in those remote regions, sending off a group of Capuchos from Portugal to Malacca, yet making the Malacca convent dependent on the Observant Province of São Tomé in India until a Discalced province was created later on. ${ }^{18}$ In Trindade's account, the arrival of the Portuguese friars at Malacca in 1585 was occasion for rejoicing, with the bishop and captain escorting them "with great pomp and solemn procession" to their convent. ${ }^{19}$ Keen to downplay the evident internal strife created by the eviction of the Castilian friars (and to avoid the accusation of gloating over this victory for both the Portuguese Observants and Discalced Franciscans), Trindade recorded that the men from Manila accepted their fate serenely: "The friars of the Custody of São Gregório who were there, seeing what they had to do by order of the King and the Minister General, lowering their heads like the sons of obedience, left behind that convent for their custody" (Trindade, 1962-1967, III: 384-391). Contemporary documents, however, reveal that this transition was anything but pacific, mentioning the "revolts that happened there about the Castilian padres not wanting to hand over the house" (Ibid., III: 390, n.5). More important to Trindade, however, was to confirm that his Observant Província de São Tomé had always cooperated with the Discalced friars at Malacca. It should not come as a surprise that the memory of these internal conflicts would cause discomfort for later Franciscan chroniclers. When Frei Jacinto de Deus produced his history in the 1670s, he could not avoid a lengthy discussion of the problems occasioned by the different groups of Franciscans in Asia and the disputes created by shifting jurisdictions over the decades (Deus, 1690: 354-423).

\section{PIOUS HEROES IN THE EAST}

Franciscan chroniclers were not only intent on revealing proof of ancient pedigrees and the rights and privileges bestowed upon missionary friars. They also presented accounts of the virtuous deeds of their men, not simply to add to the voluminous catalogues of missionary heroes, but rather to prove that Franciscan efforts were more ambitious and more valiant that those of their peers. Competition, here again, was the spur that set Franciscan pens in motion, particularly as a counterpoint to Jesuit historiographical efforts. It will suffice to look at two cases: the first mission to China by Fray Pedro de Alfaro; and the martyrdoms in Japan. Both are stories of failure - on the one hand, Alfaro's failure to remain in China to transmit the gospel; on the other, the destruction of Franciscan missionary endeavors in Japan. But both events were remembered as episodes of exemplary virtue, of virtue thwarted by evil, or of the supreme virtue of self-sacrifice. These, Franciscan chroniclers claimed, were the key virtues of the Seraphic family, regardless of their outcomes in this world.

The story of Pedro de Alfaro has been mentioned above, but it is worth the effort to recapitulate its main outlines. Alfaro was named head of the new Discalced custody in the Philippines in 1577, arriving in Manila the following year. His ambition was not limited to the Spanish colony or even the Philippine islands. He immediately set his sights on China. In 1579, he therefore traveled to the China coast and made his way to Canton but failed to convince the local authorities to grant him permission to reside within the Ming Empire. Retreating to Macau, he and his companions created a new convent in the Portuguese colony before being forced from the city. Alfaro died in a shipwreck near the Vietnamese coast on his voyage westward in 1580, leaving the issue of the dividing line between Portuguese and Castilian claims in Asia to be settled in Rome by others.

Alfaro's story was repeated in several early modern chronicles. Perhaps the most widely circulated version appeared in one of the first substantial accounts of China to be published in Europe, the widely-reprinted Historia de las Cosas mas notables, Ritos y Costumbres del gran Reyno de la China (first ed., 1585) by the Augustinian friar Fray Juan González de Mendoza (1545-1618). The first part of the book was based on the writings of fellow Augustinians who visited Fujian Province in the mid1570 s, while the second part contains an account of Alfaro's visit to Canton in 1579 , and a third part tells of the brief visit made by Fray Martín Ignacio de Loyola (15501606) to Fujian and Guangdong Provinces in 1582. Alfa- 
ro's journey is described as a "miraculous entry" into China, his seven-month stay the source of many "notable and curious" details (González de Mendoza, 1586: 265). In contrast to the Society of Jesus, whose members (it was widely known from their own printed letters) had turned their backs on China in favor of Japan, the Franciscans immediately desired to enter the Ming Empire as soon as they learned of its grandezas y secretos. Such was their drive that the friars were willing to disregard the governor of the Philippines, who tried to dissuade them, and to risk capture by pirates to reach the mission field (Ibid., 267). Guided by the hand of God, Alfaro and three companions survived a shipwreck off the China coast and made it to their destination, where they remained until they were forced to retreat.

This narrative was reproduced in successive Franciscan chronicles. Each new version dwelt on the heroic virtues of Alfaro and his companions, as well as on their audacity in braving dangers to spread the gospel. But there was one crucial question that demanded explanation: Why did they fail? If divine will could transport them around the world to the gates of the Ming Empire, proving its protective presence with several miracles, why was it not sufficient to change the hearts of the Chinese? After all, Alfaro's desire to enter China was reinforced by his estimation that its inhabitants were "discreet and able people, and with good capacity for understanding, something that facilitated his wishes and persuaded him that it would be easy to make them understand the things of God" (González de Mendoza, 1586: 267). The reason given for the friars' failure was the lies told by the interpreter who stood between them and the Chinese authorities. In other words, the Franciscans were not to blame. González de Mendoza describes how their interpreter fabricated his own version of the friars' intentions and undermined their statements in several meetings with Chinese officials. To make matters worse, the Portuguese officials at Macau denounced the friars to their Chinese counterparts, suggesting that they were spies, out of fear that the Castilians might interfere with their lucrative trade (Ibid., 283-302).

Fray Marcelo de Ribadeneira's 1601 chronicle offered a shortened version of Alfaro's story, while adding accounts of the travails of other Franciscans on the China coast. Most importantly, he underscored the friars' unyielding desire to take on what had become understood as the greatest challenge in all of Asia, getting into the seemingly impenetrable Ming Empire (or convincing their superiors in Manila that such an effort was worthwhile):

In many servants of God the drive for the conversion of souls is insatiable, affecting them like the sparks of fire spread through reeds, which are the infidels who are empty of the knowledge of their creator and God. All of the religious who have arrived and who will arrive in the Philippines go with very great desires to evangelize Christ crucified to the idolaters of the great kingdom of China, even though they must surrender themselves to what holy obedience demands, moderating their holy desires (Ribadeneira, 1601: 102).
But the friars' resignation to the will of God (and king, and bishop) did not prevent a number of other Franciscans from reaching China. Ribadeneira recounted the voyages of several whose expeditions to Macau or elsewhere in Asia were blown off course towards Chinese shores. Fray Geronimo de Burgos, for example, sought to reach the Portuguese colony with six companions in 1582 , but found himself in "another port of the Great China", where they were captured by Ming authorities. The friars were jailed in Canton; in sum, Ribadeneira reported, they spent "more than five months in jails, discomforts, hungers, waters, colds, prisons, and many other calamities and labors, the Lord always conserving them so as to augment their merits, as well as to testify to what they had seen, and so that they would see what preachers of the gospel would suffer among those infidels" (Ribadeneira, 1601: 116).

After the story of Jesuit success in China began to spread in Europe, above all with the publication of Trigault's De Christiana Expeditione apud Sinas (first published fourteen years after Ribadeneira's volume), Franciscan chroniclers felt compelled to return to the story of Alfaro's failure. Frei Paulo da Trindade picked up Ribadeneira's line, yet he omitted the allegation that the Portuguese at Macau played a nefarious role in the affair. Trindade recounts the story succinctly, highlighting the role of the unfaithful interpreter, whom he calls a Chinese "renegade from Macau" who never told the truth to either the Franciscans or the Ming authorities. Trindade notes that the missionaries were able to set up an altar in their appointed lodgings, where "to the glory of God and of our padre St. Francis, they said the first masses that were said in this city". In this version, the Portuguese at Macau had learned of their arrival and, manifesting an ardent desire for a Franciscan community in their midst, had urged the friars to set up a convent in the colony on their way back to Manila. According to Trindade, Alfaro realized that he could make no headway in China without learning the language, and "thought it good advice to go to the Portuguese at Macau." Trindade concludes his discussion by noting that other Franciscan attempts to remain in Canton met similar results. Describing a visit by two friars, perhaps in the early seventeenth century, he remarks of the Chinese that "the great caution that they use with foreigners, and the weight of the delights of the flesh and vices in which they live are great impediments for the divine word and the preaching of the holy gospel to bear fruit in them" (Trindade, 1962-1967, III: 510-517).

Curiously, despite the renewed attempts by Franciscans from Manila to enter China after 1633 and the sporadic, yet sustained, Castilian missions over the course of the following decades in Shandong Province in Northern China, chronicles omit those chapters of the East Asian missions. ${ }^{20}$ The reasons for this lacuna are unknown, but it is likely that the Portuguese war of independence (1640-1668) and the ambiguous position of some of the Franciscans with regard to the Chinese Rites Controversy (and thus the unwillingness of Franciscan chroniclers to include discussions of the later seventeenth-century 
Chinese missions) were responsible. In his Vergel de Plantas, written in the 1670 s, Frei Jacinto de Deus gave an overview of Alfaro's failed attempt to enter China. His readers were reminded of the timorous interpreter whose fear made the friars "less understood, Christ ignored, and the pagans more confused, because knowing that it would displease his audience if he showed them to be blind and wrong, and made the false and faked divinity of their idols known, he quieted the truth of the gospel and turned its preaching towards other ends." ${ }^{21}$ As a result, Frei Jacinto noted, the worthy Alfaro decided to head for Macau "to live some time among the Portuguese, until he learned the Chinese language" (Deus, 1690: 115-116). To be sure, the issue of language lay at the heart of the Chinese Rites Controversy, although it would perhaps be too much to argue that this was on Frei Jacinto's mind when he wrote about Alfaro's tongue-tied stay in Canton. Frei José de Jesus Maria, who wrote his chronicle in the mid-eighteenth century, also eschews any sustained discussion of the Franciscan missions in China, only listing the names of the friars who entered China from Alfaro's time until his own. He does not elaborate on the activities of these men, whether Spanish, Italian, or Portuguese, but he does refer to the papal bulls related to the Chinese Rites (Jesus Maria, 19411950, I: 191-194).

The story of Franciscan failure in Japan is a useful counterpoint to the story of Pedro Alfaro's rejection in China. In Japan, the specter of missionary competition appears clearly, with chroniclers arguing not simply over precedence. At issue were the deaths of the twenty-six martyrs of Nagasaki. The course of events that led to the crucifixions on February 5, 1597, involved many factors, but can be resumed briefly as follows. After completing his conquest of Kyushu in the late 1580 s, the military hegemon of Japan, Toyotomi Hideyoshi (1537-1598), launched an assault on the Korean peninsula in 1592. The considerations of foreign policy made Hideyoshi contemplate the need for overseas vassals or trading partners that is, some other group beyond the Portuguese. An embassy from the Philippines, led by Franciscan friars chosen for the task by the colonial government, visited the hegemon's court. Desirous to enjoy the Spaniards' friendship and envisioning their fealty, Hideyoshi extended a welcome to the friars - even though he had outlawed Christianity in the island empire in 1587. In view of the fact that Hideyoshi had not enforced his proscription, the Franciscans dismissed Portuguese and Jesuit pleas to refrain from proselytizing. From their base in Central Japan, the friars established a small network of Christian communities in the shadow of the hegemon. The cordial terms of their residence in Japan were overturned abruptly on the occasion of a trade dispute in 1596 over the cargo of a wrecked Spanish vessel San Felipe, confiscated on Hideyoshi's orders, when the friars overplayed their diplomatic hand. Allegedly, the Portuguese and the Jesuits in Japan encouraged reprisals against their commercial and spiritual rivals. When Hideyoshi decided to move against the Spaniards and the Franciscans, he did so with an eye on retaining access to the lucrative trade from Macau; Portuguese and Jesuit monopolies were thus preserved. Rather than uproot the Christian plant at once, he exacted an exemplary punishment against the newest shoots, the Franciscans and a number of their lay Christians. Three Japanese who had joined the Jesuits were added to the main group of victims (Elison, 1991: 109131). Other, equally dramatic episodes of martyrdom would follow. In the event, Jesuits suffered in far greater numbers than friars, whether Franciscan, Augustinian, or Dominican.

As the years passed, the chroniclers who recounted the story of the twenty-six martyrs were keen to point out that Franciscan blood had been the first to fall upon Japanese soil. Moreover, Franciscan sacrifices were more dramatic and their relics more miraculous than those of their rivals. For the chroniclers who had been at the scene in Nagasaki, such as Fray Marcelo de Ribadeneira, the first challenge was to get the basic facts straight. News from Japan arrived with bursts of pathos in late sixteenth-century Europe, and was eagerly received by readers who had witnessed the Jesuits' parading of four Japanese boys across southern Europe in the mid-1580s. ${ }^{22}$ The island empire thus existed in the minds of Europeans as an exotic place, yet one associated with the flowering of the church, not with its tragic destruction. Confusion reigned, Ribadeneira maintained, and it was his job to sort out fact from fiction: "Recently there have been so many authors, whose relations are so varied, that I consider myself obliged to give a report of the truth." (Ribadeneira, 1601: prologue).

As an eyewitness to the martyrdoms, Fray Marcelo could be trusted more than the compilers of news that had passed through several hands before it reached printing presses. The rebuttals of a testigo de vista were a useful shield against the friars' accusers, especially the suspicion that they had imprudently awakened Hideyoshi's ire. Ribadeneira responds with entire chapters devoted to the Franciscans' prudence ("very similar to that of the saints") or their relations with the indigenous clergy (Ribadeneira, 1601: 437-443, 446). In taking this approach, he resembles his former colleague, Fray Juan de Santa María (1551-1622), the superior of the Discalced Province of San José in Spain. ${ }^{23}$ The preface of Santa María's account of the martyrdoms, Relacion del Martirio que seys Padres Descalços Franciscos, tres hermanos de la Compañia de Iesus, y decisiete Iapones Christianos padecieron en Iapon (Madrid, 1601), boasted a long list of informaciones autenticas that were his sources. Most important were the reports from the governor of the Philippines, the chief of the Cabildo, and the Archbishop of Manila. One notes with some surprise that Santa María leans heavily on a report written by the Jesuit missionary chronicler Luís Fróis (1532-1597) whose letters from Japan were widely read in Europe..$^{24}$ Ribadeneira, too, cited Jesuit testimony about the future martyrs' holy way of the life, citing the opinions of the "very learned priests of the Society" who welcomed the friars' presence in Japan (Ribadeneira, 1601: 468-470). 
Leaving aside the dramatic scenes, let us look at how the events were recorded in later Franciscan chronicles. After the Tokugawa shogunate proclaimed the edict of expulsion of the Catholic clergy in 1614, the persecution intensified in Japan, leading to significant numbers of martyrdoms among the clergy and hundreds of dead among the laity. Keeping track of the martyrs was a complicated task: Communication with the surviving Christians in Japan became ever more hazardous if not impossible, making it difficult to compile accurate reports of those killed. But the spirit of competition between the religious orders - augmented by a climate of mutual recrimination over whose actions had set off the persecutions - intensified as the years passed.

The war waged between the orders over Japan was thus a war of words over the martyrs' memory. Getting the story straight, in the way Ribadeneira and Santa María attempted to do, was the surest way to advance the official proclamation that would elevate the Japan martyrs into the ranks the beatified. And since the fury of the persecutors continued unabated, it was necessary to keep Rome informed with complete catalogues of martyrs, a task which fell to chroniclers outside of Japan. ${ }^{25}$ One such example of this grim accounting was Fray Diego de San Francisco's Relacion Verdadera, y Breve de la Persecucion, y Martirios que padecieron por la confession de nuestra Santa Fee Catholica en Iapon, quinze religiosos de la Provincia de S. Gregorio, de los Descalços del Orden de nuestro Seraphico P. S. Francisco de las Islas Philipinas (Manila, 1625). This text addressed the martyrs who suffered between 1613 and 1624, focusing on the Discalced friars from Manila but also including accounts of "many other religious martyrs from other orders and seculars of different statuses." Center stage is nevertheless occupied by the Franciscans, as the author states in his dedication to King Philip IV, patron of the missions: "They came with enflamed desires to suffer for Christ, and now return roasted and burnt by his divine love, made into new Lawrences and Vincents of this new Church of Japan, crowned with a thousand laurels and honored with infinite trophies that they gained by their glorious martyrdoms." The list offered here, which culminates with an account of Fray Luis Sotelo's death in 1624, is presented as definitive, standing in contrast to other reports of the type denounced by Marcelo de Ribadeneira a quartercentury earlier, which were nonetheless still circulating among European readers:

\footnotetext{
So many triumphs have produced such variety, and even confusion, about how to report the truth of these happy events. Every day we see it happen. Since all of the witnesses of a public event want to be its chroniclers, the truth becomes clouded, because, quot capita, tot senten$t_{i a e^{26}}$, and they all want to tell of it and dress it up in the livery of their ingenuity. This has happened in the telling, writing, and narrating of the martyrdoms of the holy martyrs of Japan, and their true circumstances, and so it seemed very important and necessary to reveal the truth clearly, to separate the dubious from the certain, so that the truth of the story be known and understood (San Francisco, 1625: prologue).
}

The first point that was clarified in this Relacion Verdadera was the order of the martyrdoms, starting with the twenty-six martyrs of Nagasaki in 1597. The dispute between the Jesuits and the Franciscans over precedence again appears in this context. San Francisco refers to this first group as the "holy protomartyrs of Japan", led by Frey Pedro Baptista (b.1542) and his five companions, as well as the "twenty Japanese saints". This reference to an undifferentiated pool of Japanese martyrs was a manifest slap at the Jesuits, who counted the trio of João de Goto, Paulo Miki, and Diogo Kisai among their number. San Francisco continued to list those who died in other early persecutions, claiming that the second group comprised "eight Japanese Christians, baptized by our religious at the court of the emperor of Japan" (San Francisco, 1625: $1 v$ and 3). So not only did this chronicler assert Franciscan precedence in the Japanese martyrdoms, he did so to the exclusion of other religious orders or their lay followers.

Clearly, the martyrological accounting was not an exercise that would disappear quickly as the seventeenth century wore on. Since the intercessory power of the beatified martyrs was at stake - the power that secured special grace for the members of the martyrs' religious orders - friars and Jesuits fought for decades over the memory of Japan. For its part, the Papal Curia approached the task of beatifying the Japan martyrs very slowly. It was only in 1627 - thirty years after the twenty-six martyrs died - that it authorized the public veneration of them as blessed. It was clear that Rome did not appreciate the flood of texts composed by members of religious orders aimed at speeding up its deliberations. Indeed, by the mid-1620s, such was the force of lobbying that Urban VIII (r.1623-1644) prohibited the unauthorized celebration, whether in liturgies or printed books, of any holy men or women, martyrs included. Papal decrees in 1625 (reiterated in 1634) promised severe punishments for those who contravened Rome's will (Ditchfield, 2008). Chroniclers within the religious orders, including the Franciscans discussed here, nevertheless continued to compose histories that included accounts of the Japan martyrs, since their numbers continued to increase well into the 1640 s. The crucial point about Urban VIII's prohibition was that new texts could not be published; they could be produced for internal consumption among religious communities as long as they remained in manuscript.

For those martyrs who had already been beatified, celebrations were licit. Since the majority of the Japan martyrs were only beatified in the 1860 s, with some recognized only in 1981 and 2008, this meant that the memory of the twenty-six martyrs garnered outsized attention in early modern printed texts. In the late 1630s, Frei Paulo da Trindade (whose text was destined for publication, albeit not until the 1960s) not only retold the story of the Franciscan expedition to Japan and the Nagasaki martyrdom in 1597 , but also included a three-chapter discussion on the miracles occasioned by relics of the six Franciscans. Trindade claims that the crucified friars, while still 
on their crosses, showed "no ugliness at all", and that, unlike the bodies of other victims, which reeked at four days, "not even at sixty did these emit any bad odors." Not even the crows, known in Japan for being "very carnivorous" and for flocking to dead bodies to "eat their eyes", approached the blessed bodies to despoil them. Furthermore, when a group of Portuguese traders about to head back to Macau forty days after the crucifixion decided to sever a toe from Fray Pedro Baptista, fresh blood flowed from the wound - further proof of the divine favor. Trindade also recorded that mysterious signs began to appear on Friday nights in Nagasaki after February 5, 1597: "Lights like candles were seen heading out in procession from the site of the martyrdom, whence they descended to the leper hospital, the first house in which they lodged in that place, and thence to the hermitage of Our Lady." Others claimed, as the chronicler reported, that Baptista was not dead, since he was seen "on Fridays and Saturdays, saying mass fully dressed at the leper hospital as he used to do, and that one full day he disappeared from his cross" (Trindade, 1962-1967, III: 545-547). Relics were nevertheless gathered by Spanish and Portuguese visitors to the Nagasaki execution ground, items that were to be distributed among Franciscan houses from Manila to Salamanca, and especially to Macau and Bassein, the Indian birthplace of Trindade's Discalced confrere, Frei Gonçalo Garcia (b.1557)27 (Ibid., 559-561).

It is a testament to the vigor with which early modern religious chroniclers fought their battles of pen and ink that the subject of the Nagasaki martyrs still provoked debate in the 1670s. Frei Jacinto de Deus revisited the issue in his Vergel de Plantas, reminding his readers that the first martyrs in Japan were Franciscans, even if they were not the first to arrive there. According to Frei Jacinto: "their zeal would not permit them to not be the first in the spilling of their blood and the sacrifice of their lives." Frei Jacinto felt compelled to reiterate this point because attentive readers of Luis de Guzmán's 1601 Jesuit history of the Japan mission would have noticed a brief mention of four priests who died in early 1590s after being poisoned at Hirado (Guzmán, 1601: II:542). This reference, which is mentioned in the context of other events, is not heralded in Guzmán's text and does not merit its own chapter. Frei Jacinto nevertheless cites that text and mentions "others" who also point to this Jesuit quartet. But he asserts that "even if they died by poison, they cannot be adjudged true martyrs". His argument hinges on the need for odium fidei, which he claims did not exist in Japan prior to Hideyoshi's persecution of the Philippine friars. Considering the moments prior to 1597 through distinctly rose-colored glasses, he claims that "at that time the affection for our Holy Faith was growing in the hearts of the Japanese, and in none of them was there any aversion to our Holy Law, nor in the princes hatred for Christ our Lord." Of course, Frei Jacinto admitted, "only God can be the judge of occult matters", but this did not suffice to take the title of protomartyrs away from the six Franciscans crucified at Nagasaki. The best evidence that he could offer was the same that was offered by other friar chroniclers - the recognition of the twenty-six martyrs as the first to die for the faith in Japan was affirmed by "Padre Luis Fróis, da mesma Companhia" (Deus, 1690: 118-119).

\section{OUT OF THE TOMB OF OBLIVION}

The Franciscan chroniclers whose works have been surveyed here sought to preserve the institutional memory of their orders' deeds in Asia during times of upheaval. The early modern missions in China, Japan, and Southeast Asia occurred in lands beyond colonial control, where good relations with the powerful were never certain. Even in the seats of colonial power, the imperial fault line between Portuguese and Spanish dominions made the business of creating religious communities difficult. Conflicts arising from divergences within the Franciscan family further complicated matters: Just as no branch could claim jurisdiction over all friars in the East, so none was sole master of Franciscan memory.

Chroniclers from Portuguese or Spanish origins, or Observant or Discalced provinces had different views on the history of Franciscan efforts. They also had strong views on the relative importance of the work of their brethren as opposed to that of members of other orders, especially the Jesuits. The issues at stake were primarily judged on the basis of precedent and precedence: Who had the longest claim to a presence in the East? Who arrived first? Who made the glorious sacrifice of martyrdom first? These questions could be answered in different ways, and each order's chroniclers took up the pen to advocate their brethren's cause before European readers. But answers were needed. As Frei Paulo da Trindade noted in the conclusion to his Conquista Espiritual do Oriente, points of honor had to be resolved. It was necessary to bring to light the truth about the Franciscans' manifold works in Asia, accomplishments that were "almost buried in oblivion as if they did not count" (Trindade, 1962-1967, III: 567).

Surprisingly, the surge in chronicles of religious orders published in Europe during the eighteenth century did not include specific works on the Franciscans' East Asian missions. There were chronicles devoted to the European provinces, and these are major works of early modern historiography. But there were none recapitulating the friars' work in China, Japan, or Southeast Asia as stand-alone volumes. Recall that even Frei José de Jesus Maria's Azia Sinica e Japonica remained in manuscript until the twentieth century. What accounts for the abandonment of the missions by these later chroniclers? Most likely, the staggering number of polemical publications devoted to controversial issues such as the Chinese Rites and the Malabar Rites sapped reader interest for older episodes of missionary conflict - especially since this polemical character was unlikely to disappear from new accounts. The Franciscans would therefore have to endure a long wait for new histories of their missions in East Asia to appear. This is a task that still invites historians to take up their pens. 


\section{NOTES}

1 A broad discussion of early modern Franciscan historiography with special focus on India is found in Souza de Faria (2013: 199-246).

2 To be sure, Orazio Torsellino (De Vita Francisci Xavierii, first ed. 1594) and João de Lucena (História da Vida do Padre Francisco Xavier, first ed. 1600) had already presented similar points with regard to Xavier. The later texts mentioned here would stress the geography of his actions, as well as those of his followers, rather than Xavier's biography.

3 Documents relating to the medieval Franciscan expeditions to "Tartary" are found in vol. 1 of Van den Wyngaert (1929-1942).

4 The terms custódio and vigairia refer to Franciscan group of linked communities of friars in a given geographic region. They were considered subordinate to larger provincias, but often existed at significant geographic remove from their provinces, especially during the period of Franciscan expansion in Asia in the late sixteenth century.

5 Lisboa's dates are off: The expedition left Avignon in December, 1338.

6 The Reformed Observants were part of the branch of Spanish friars called Alcantarines, after Pedro de Alcantara (14991562). Unlike the rest of Europe, which saw a strong surge in Capuchins in the late sixteenth century, Portugal had no properly Portuguese Capuchin houses until the twentieth century (French and Italian Capuchins were present in the seventeenth century in Lisbon). The Capuchos refer to the communities as being of the "most strict observance", in contrast to the Conventuals and even the Observants.

7 The articulation of Franciscan administration in Portuguese Asia is discussed in Lopes (1963).

8 Frei Jacinto states that Trindade's Conquista Espiritual do Oriente "exists in manuscript in Portugal with the hope it will be printed". This only occurred nearly three hundred years later.

9 This "João Peres de Marchena" seems to be the mixture of the names of two Franciscans who lived in the Franciscan convent of La Rábida, which welcomed Columbus. Historical records indicate a Juan Perez, and an Antonio de Marchena, with former sailing on Columbus's first expedition. The confusion appears to date from sixteenth century works.

10 Indeed, the Franciscans under Frei Henrique de Coimbra's (d.1532) leadership sailed with Pedro Álvares Cabral on his 1500 mission which stopped on the coast of Brazil before heading to India.

11 Further on these early Jesuit missions can be found in Witek and Sebes (2002).

12 Trindade does not mention two other bishops who sailed to India before Vaqueiro. See the notes by Fernando Félix Lopes in his edition of Trindade's Conquista Espiritual do Oriente, 1962-1967, I: 93-94.

13 The role of Franciscans in organizing the Goan archiepiscopal see, as well as their missionary activity in the region of Goa, is surveyed in Souza de Faria (2013: 109-145).

14 See, for example, Ortelius's 1570 Asiae Nova Descriptio, where Cataio is located to the north of the provinces of China; John Speed's 1630 The Kingdom of China, where Cathaya lurks north of the Great Wall; Hondius's 1633 Nova Totius Terrarum Orbis Geographica ac Hydrographica Tabula, which indicates Cathay, with its main cities, off in the northeastern Siberia; Johannes Blaeu's 1650, Asia noviter delineata, with Cathaya in the same spot.

15 The history of the papal bulls regarding missionary rights in Japan are discussed in Lach (1965-1993, I:2: 705-706 and 718-719).

16 Some of these Philippine friars went to Japan as ambassadors of the Spanish colonial government in Manila, thereby exempting them from Gregory XIII's prohibition. Frei Paulo da Trindade describes the news of Hideyoshi's request for an embassy from Manila as a divine intervention, making it possible for the Franciscans to visit Japan "without disobeying or risking excommunication by His Holiness.” (Trindade, 1962-1967, III: 535)
17 Frei Paulo da Trindade also relates the story of the Castilian friars in Cochinchina and Siam, here indifferent to the jurisdictional conflicts between Portuguese and Spaniards in Southeast Asia.

18 The complicated creation of the Franciscan custody of Malacca is discussed in Lopes (1997).

19 Other Portuguese friars took charge of the convent at Macau in the same year. See Fernando Félix Lopes's notes to Trindade, 1962-1967, III: 511, n.1.

20 Further on the Franciscans in Shandong is in Mungello (2001).

21 Determining precisely who this bad interpreter was is very difficult. González de Mendoza mentions a Chinese slave who had been purchased by a Castilian merchant and who accompanied Alfaro, as well as Portuguese-speaking Chinese at Canton. Ribadeneira mentions these two as well, while Trindade adds still more Chinese speakers of Spanish and Portuguese. By the time the story is retold by Jacinto de Deus, all of these individuals were reduced to one interpreter.

22 The Jesuits' publicity efforts in bringing Japanese youths to Europe is succinctly discussed in Elisonas (2007).

23 Recall that the Custody of San Gregorio in the Philippines was separated from the Province of San José in Spain in the years following Alfaro's original journey to the Philippines.

24 Fróis's text was published in Italian, but circulated in manuscript in other languages. See Fróis (1599).

25 Further on this conflict is in Brockey (2014: 378-385).

26 The Latin aphorism means: "There are as many opinions as there are heads".

27 Further discussion of the cult of one of these martyrs, Fray Felipe de Jesús, can be found in Conover (2011).

\section{REFERENCES}

Brockey, Liam Matthew (2014) The Visitor: André Palmeiro and the Jesuits in Asia. Harvard University Press, Cambridge, Massachusetts.

Conover, Cornelius (2011) "Saintly Biography and the Cult of San Felipe de Jesús in Mexico City, 1597-1697'. The Americas 67 (4): 441-466.

Deus, Frei Jacinto de, OFM (1690) Vergel de Plantas, e Flores da Provincia da Madre de Deos dos Capuchos Reformados. Miguel Deslandes, Lisbon.

Ditchfield, Simon (2008) "Tridentine Worship and the Cult of the Saints". In Cambridge History of Christianity, Vol. 6: Reform and Expansion, 1500-1650, edited by R. Po-Chia Hsia. Cambridge, Cambridge University Press: 201-224.

Elison, George (1991) Deus Destroyed: The Image of Christianity in Early Modern Japan. 3rd edition. Harvard University Press, Cambridge, Massachusetts.

Elisonas, J.S.A. (2007) "Journey to the West". Japanese Journal of Religious Studies, 34 (1): 27-66.

Fróis, Luís, SJ (1599) Relatione della gloriosa morte de XXVI. posti in croce Per comandamento del Re di Giappone, alli 5. di Febraio 1597. de quali sei furno Religiosi di San Francesco, tre della Compagnia di Giesù, \& dicisette Christiana Giapponesi. Pacifico Pontio, Milano.

González de Mendoza, Juan, OSA (1586) Historia de las Cosas mas notables, ritos y costumbres del gran Reyno de la China... Segunda Parte de la Historia del Gran Reyno de la China: en la qual se ponen tres libros: ... El segundo, el viaje milagroso que hizieron a este mesmo Reyno el padre fray Pedro de Alfaro Custodio en las islas Philippinas de la Orden de sant Francisco, y sus compañeros / El tercero contiene un Itinerario del Padre Custodio de la mesma Orden, fray Martin Ignacio, q fue de España hasta la China, de donde bolvio a España por la India Oriental, despues de aver dado buelta al mundo: tratanse en el cosas muy notables que vio, y entendio en el viaje. Querino Gerardo Flamenco, Madrid.

Jesus Maria, Frei José de (1941-1950) Azia Sinica e Japonica: Obra Póstuma e Inédita do Frade Arrabido José de Jesus Maria, ed. C.R. Boxer. 2 vols. Escola Tipográfica do Oratorio de S. J. Bosco (Salesianos), Macau. 
Lach, Donald and Van Kley, Edwin (1965-1993) Asia in the Making of Europe. 3 vols. in 9 bks. University of Chicago Press, Chicago.

Lisboa, Frei Marcos de, OFM (1615) Parte Segunda das Chronicas da Ordem dos Frades Menores, e das outras ordens segunda \& terceira, instituidas na Igreja per o sanctissimo Padre sam Francisco, ed. Frei Luis dos Anjos, OFM. Pedro Craesbeeck, Lisbon.

Lopes, Fernando Félix, OFM (1962) "Os Franciscanos no Oriente Português de 1584 a 1590". Studia, 9 (Jan.): 29-142.

Lopes, Fernando Félix, OFM (1997) "Custódia de S. Francisco de Malaca: Sua Fundação". In Colectânea de Estudos de História e Literatura, edited by Fernando Félix Lopes, OFM, 3 vols. Academia Portuguesa da História, Lisbon: 3:241-263.

Mungello, D.E. (2001) The Spirit and the Flesh in Shandong, 16501785. Rowman \& Littlefield, Lanham, Maryland.

Ribadeneira, Fray Marcelo de, OFM (1601) Historia de las Islas del Archipielago, y Reynos de la Gran China, Tartaria, Cuchinchina, Malaca, Sian, Camboxa y Iappon, y de lo sucedido en ellos a los Religiosos Descalços, de la Orden del Seraphico Padre San Francisco, de la Provincia de San Gregorio de la Philippinas. Gabriel Graells y Giraldo, Barcelona.

San Francisco, Fray Diego de, OFM (1625) Relacion Verdadera, y Breve de la Persecucion y Martirios que padecieron por la confession de nuestra Santa Fee Catholica en Iapon, quinze religi- osos de la Provincia de S. Gregorio, de los Descalços del Orden de nuestro Seraphico P. S. Francisco de las Islas Philipinas (aonde tambien se trata de otros muchos Martires Religiosos de otras Religiones, y seculares de differentes estados. Todos los quales padecieron en Iapon desde el año de 1613 hasta e de 1624). Thomas Pimpin, Manila.

Santa Maria, Fray Juan de, OFM (1601) Relacion del Martirio que seys Padres Descalços Franciscos, tres hermanos de la Compañia de Iesus, y decisiete Iapones Christianos padecieron en Iapon. Juan Iñigue de Lequerica, Madrid. http://bdh-rd.bne.es/viewer.vm?id $=0000120382 \&$ page $=1$ [consulted $10 /$ September/2015].

Souza de Faria, Patricia (2013) A Conquista das Almas do Oriente: Franciscanos, catolicismo e poder colonial português em Goa (1540-1740). Viveiros de Castro, Rio de Janeiro.

Trigault, Nicolas, SJ (1615) De Christiana expeditione apud Sinas suscepta ab Societate Iesv. Christoph. Mangium, Augsburg.

Trindade, Paulo da (1962-1967) Conquista Espiritual do Oriente, ed. Fernando Félix Lopes, OFM. 3 vols. Centro de Estudos Históricos Ultramarinos, Lisbon.

Van den Wyngaert, Anastasius, OFM (1929-1942) Sinica Franciscana. 4 vols. Collegium S. Bonaventurae, Quaracchi.

Witek, John, SJ and Sebes, Joseph, SJ (2002) Monumenta Sinica. Institutum Historicum Societatis Iesu, Rome. 